\title{
REGULATION OF PHENYLALANINE AMMONIA-LYASE ENZYME IN ANNONA FRUIT: KINETIC CHARACTERISTICS AND INHIBITORY EFFECT OF AMMONIA
}

\author{
R. MALDONADO, O. GOÑI, M.I. ESCRIBANO and C. MERODIO ${ }^{1}$ \\ Departamento de Ciencia y Tecnología de Productos Vegetales \\ Instituto del Frío \\ Consejo Superior de Investigaciones Científicas \\ José Antonio Novais, 10. Ciudad Universitaria, 28040 Madrid, Spain
}

Accepted for Publication April 10, 2006

\begin{abstract}
In this work, we analyzed the kinetic properties of phenylalanine ammonia-lyase (PAL) extracted from "cherimoya" (Annona cherimola Mill.) fruits ripened at ambient temperature (20C) and stored under several environmental conditions, including high $\mathrm{CO}_{2}$ levels (20\%) and low temperature (6C). The effect of different ammonia-related compounds on cherimoya PAL activity was also evaluated. PAL exhibited two different $\mathrm{K}_{m}$ values for L-phenylalanine (L-Phe) and negative substrate cooperativity, with Hill coefficient $\left(\mathrm{n}_{\text {app }}\right)$ values reaching 0.64 and 0.71 for low temperature and high $\mathrm{CO}_{2}$ levels, respectively. The kinetic analysis revealed that ammonia produced mixed inhibition of PAL enzyme, with inhibition constants $\left(\mathrm{K}_{i}\right.$ and $\left.\mathrm{K}_{i}^{\prime}\right)$ values of $0.57 \pm 0.2 \mathrm{mM}$ and $2.54 \pm 0.2 \mathrm{mM}$. We propose that the regulation of PAL by ammonia inhibition and the negative cooperativity may be essential in adjusting the active phenylpropanoid metabolism in Annonas to the requirement of L-Phe and in consequence, to the carbon skeleton demand for other anabolic pathways.
\end{abstract}

\section{PRACTICAL APPLICATION}

Phenylalanine ammonia-lyase (PAL) catalyzes nonoxidative deamination of L-phenylalanine to form trans-cinnnamic acid and an equimolar amount of ammonium ion. In most systems studies, accumulation of phenylpropanoid compounds under stress conditions is the result of increased PAL activity. Regulation of PAL activity has important technological and

${ }^{1}$ Corresponding author. TEL: 34-91-5492300; FAX: 34-91-5493627; EMAIL: merodio@if.csic.es

Journal of Food Biochemistry 31 (2007) 161-178. All Rights Reserved.

(C) 2007, The Author(s) 
physiological significance for controlling the quality of fruit and vegetables. The fact that endogenous regulator as ammonia was found to inhibit PAL activity may prove essential in adjusting PAL activity to the metabolic changes imposed by different storage conditions. Moreover, the efficiency of postharvest technologies applied to maintain fruit quality could be related to their capacity to modify endogenous ammonia levels in the fruit and to control the displacement of ammonia ionizations state by means of a $\mathrm{pH}$-dependent process.

\section{INTRODUCTION}

Phenylalanine ammonia-lyase (PAL; EC 4.3.1.5.) is considered the branch point enzyme between primary (shikimate pathway) and secondary (phenylpropanoid) metabolism, and directs carbon from aromatic amino acids to the synthesis of phenylpropanoid metabolites. In the reaction catalyzed by PAL, L-phenylalanine (L-Phe) is deamined to form trans-cinnamate and ammonium ion.

The potential regulation of PAL activity is extremely complex, and different posttranslational modifications that modulate enzyme activity have been reported (Engelsma 1970; Shaw et al. 1990; Bolwell 1992; Allwood et al. 1999). Several isoforms of PAL have been identified, and it is generally considered that these isoforms represent the products of different members of the PAL gene family. In this context, in most plants it has been reported that PAL is encoded by a small multigene family of two to six members (Cramer et al. 1989; Logemann et al. 1999). Few of these genes are constitutively expressed and others are differentially induced in response to a range of biotic and abiotic stresses (Shufflebottom et al. 1993; SanchezBallesta et al. 2000; Campos et al. 2004; Wen et al. 2005). PAL has generally been described as a tetrameric enzyme, with molecular weights of approximately $330 \mathrm{kDa}$ and a homogeneous or heterogeneous quaternary structure depending on posttranslational processing, degradation or expression of truncated polypeptide subunits (Hanson and Havir 1981; Appert et al. 1994; Lim et al. 1998).

Negative cooperativity has been reported for PAL from many plant sources, most of them exhibiting high affinity for the substrate at low concentrations (Hanson and Havir 1981; Bolwell 1992; Dubery and Smit 1994). Besides, PAL inhibition by-products from branches of the phenylpropanoid pathway have been reported (Alibert et al. 1972; Jorrin et al. 1988; Jorrin and Dixon 1990; Sarma et al. 1998). 
Many reports have also been published indicating that PAL activity is moderately sensitive to several substrate analogue compounds (Dixon and Lamb 1979; Jorrin and Dixon 1990; Kim et al. 1996), and synthetic PALinhibiting substrate analogues of PAL have been developed (Hisaminato et al. 2001). The most effective is the synthetic substrate analogue 2 -aminoindan2 -phosphonic acid (AIP) (Zon and Amrhein 1992). AIP and $\alpha$-aminooxy- $\beta$ phenylpropionic acid were very effective against tomato PAL, and $\mathrm{I}_{50}$ values of 1.0 and $2.3 \mu \mathrm{M}$, respectively, have been reported (Bernards and Ellis 1991). Although ammonium is eliminated along with the pro-S hydrogen atom from L-Phe to form trans-cinnamic acid in the reaction catalyzed by PAL, to our knowledge no work has been reported on the effect of the ammonia molecule on PAL activity.

In fruits and vegetables, PAL activity has been widely studied in connection with induced phenolic accumulation in response to several kinds of stress (Ke and Saltveit 1989; López-Gálvez et al. 1996; Lafuente et al. 2001; Saltveit et al. 2005). However, little is known about the regulation of PAL enzyme in the general metabolism of fruits accumulating large quantities of polyphenols. The mesocarp tissues of "cherimoyas" (Schroeder 1951) contain many sclereids, highly lignified cells and have modified parenchymatous cells with a relatively greater abundance of tannins. We reported that in cherimoya fruit, which exhibits active nitrogen metabolism (Escribano and Merodio 1994) mainly under high $\mathrm{CO}_{2}$ levels (Merodio et al. 1998; Muñoz et al. 1999), the high nitrogen reassimilation was correlated with a high PAL activity. On the contrary, fruit showing low PAL activity accumulates high levels of endogenous ammonia (Maldonado et al. 2002a). Specifically, this metabolic situation occurs in fruit during the first days of storage at chilling temperature (6C) (Maldonado et al. 2002b). These characteristics made Annona fruit a good model to analyze the phenylalanine-cinnamate pathway and the regulation of PAL enzyme.

The aim of this work was to analyze the regulation of PAL enzyme in cherimoya fruit as a first step toward the formulation of a model for in vivo regulation of PAL in Annonas. To achieve this objective, first we analyzed the kinetic properties of PAL extracted from cherimoyas ripened at ambient temperature (20C) and stored under different environmental conditions (high $\mathrm{CO}_{2}$ levels and low temperature), in which PAL activity and the endogenous levels of ammonia are known to change. Specifically, the activation of PAL was observed in ripe cherimoya fruit as compared with fruit after harvest. The activation of PAL was also observed in $20 \% \mathrm{CO}_{2}$-treated fruit. However, in cherimoya fruit stored at low temperature (6C) for 3 days, PAL activity decreased. In the case of storage at $6 \mathrm{C}$, the decrease in PAL activity was associated with the highest ammonia concentrations in these fruits. Then, we analyzed the kinetics of PAL inhibition by ammonia. 


\section{MATERIALS AND METHODS}

\section{Plant Material}

Cherimoya (Annona cherimola Mill. cv. "Fino de Jete") fruits harvested in Almuñecar (Granada, Spain) were selected for freedom from physical and pathological defects. After $6 \mathrm{~h}$ of road transport, the fruits classified uniformly by color, size and weight were randomly divided into three groups of 20 cherimoyas each and stored in the dark at 20 and 6C. Each group was placed in separate respiration chambers $(20 \mathrm{~L})$ in a continuous flow $(100 \mathrm{~mL} / \mathrm{min})$ of humidified air (at 20 and $6 \mathrm{C}$ ) or a gas mixture containing $20 \% \mathrm{CO}_{2}+20 \%$ $\mathrm{O}_{2}+60 \% \mathrm{~N}_{2}$ (at 20C) and stored for 3 days. At the end of each treatment, four cherimoyas were randomly collected, peeled, quick-frozen in liquid nitrogen and stored at $-80 \mathrm{C}$.

\section{Extraction and Assay of PAL Activity}

The method described by Assis et al. (2001) was used for extraction and assay of PAL activity (EC 4.3.1.5). Briefly, protein extract was obtained by homogenizing $0.5 \mathrm{~g}$ of mesocarp acetone powder in $5 \mathrm{~mL}$ of $0.1-\mathrm{M}$ sodium borate buffer, $\mathrm{pH} 8.8$, containing 5-mM $\beta$-mercaptoethanol, 2-mM EDTA and $4 \%(\mathrm{w} / \mathrm{v})$ poly(vinylpyrrolidone) at $4 \mathrm{C}$. After $1 \mathrm{~h}$, the homogenate was centrifuged at $27,000 \times \mathrm{g}$ for $30 \mathrm{~min}$ at $4 \mathrm{C}$. The clear supernatant was used for enzyme assay.

The reaction mixtures contained $10 \mathrm{mM}$ of L-Phe, $30 \mathrm{mM}$ of sodium borate buffer, $\mathrm{pH} 8.8$, and $1-\mathrm{mL}$ crude extract in a total volume of $3 \mathrm{~mL}$. After 10 min of preincubation, the substrate was added and the reaction was stopped with $0.1 \mathrm{~mL}$ of $6-\mathrm{N} \mathrm{HCl}$. PAL activity was determined by the production of trans-cinnamate for $90 \mathrm{~min}$ at $30 \mathrm{C}$ under continuous shaking and measured by absorbance change at $290 \mathrm{~nm}$ using a Perkin Elmer Lambda 15 UV-Vis spectrophotometer (Norwalk, CT). Specific enzyme activity was expressed as nmol of cinnamic acid produced per hour and per milligram of protein. Protein concentration of the enzymatic extracts was measured by the method of Bradford (1976) using a protein-dye reagent (Bio-Rad, Hercules, CA) and bovine serum albumin (Sigma-Aldrich, St. Louis, MO) as a standard.

\section{Kinetic Studies}

Crude PAL-rich extract from mesocarp cherimoya tissues was used to determine the kinetic parameters and to test for ammonia inhibition. Kinetic (for L-Phe) and inhibition (for ammonia) parameters were determined from linear regression equation using the Lineweaver-Burk models (all the $r^{2}$ values were higher than 0.98). 
For inhibition studies, ammonia was added to the standard assay mixture in concentrations ranging from 2 to $16 \mathrm{mM}$. Ammonia concentrations required for $50 \%$ inhibition of PAL activity under the aforementioned assay conditions were determined graphically from semilogarithmic plots of the dose-response curves and defined as ammonia $\mathrm{I}_{50}$ values.

Concentrations of ammonia close to the $\mathrm{I}_{50}$ value at $\mathrm{pH} 8.8$ were taken to estimate $K_{\mathrm{m}}^{\prime}$ and $V_{\max }^{\prime}$. Assay ammonia concentrations were 1 and $3 \mathrm{mM}$. Experiments were performed in an L-Phe concentration range from $50 \mu \mathrm{m}$ to $10 \mathrm{mM}$. Inhibition constants, $K_{\mathrm{i}}$ and $K_{\mathrm{i}}^{\prime}$, for the inhibitor were determined by replots of slope or reciprocals apparent maximal velocities $\left(1 / V^{\prime}{ }_{\max }\right)$ obtained from primary Lineweaver-Burk plots versus the inhibitor concentration. In the secondary plots, the intercept on the inhibitor axis gives the values for $-K_{\mathrm{i}}$ and $-K_{\mathrm{i}}^{\prime}$, respectively.

To analyze the implication of the ionization state of the inhibitor molecule in PAL activity, the ammonia concentrations required for $50 \%$ inhibition of PAL were determined in the standard reaction mixture assayed at $\mathrm{pH} 9.25$ using $30 \mathrm{mM}$ of sodium borate buffer, and the $\mathrm{I}_{50}$ values at $\mathrm{pH} 8.8$ and 9.25 were calculated. The neutral molecule $\mathrm{NH}_{3}$ is a weak base and protonates rapidly to yield $\mathrm{NH}_{4}^{+}$, with a dissociation constant of $10^{-9.25}$. Consequently, at pH 9.25 the levels of $\mathrm{NH}_{3}$ and $\mathrm{NH}_{4}{ }^{+}$are equal, while at $\mathrm{pH} 8.8, \mathrm{NH}_{3}$ is trapped by $\mathrm{NH}_{4}{ }^{+}$formation and is reduced by about $30 \%$.

\section{Statistical Analyses}

Data from at least three replicates per sample were subjected to analysis of variance (Statgraphics program, STSC, Rockville, MD). Multiple variance analysis was employed to determine the significance of the data at $P \leq 0.05$. The results presented here represent data from three or more experiments performed in succession.

\section{RESULTS AND DISCUSSION}

\section{Kinetic Characterization of PAL Extracted from Fruits under Different Environmental Storage Conditions}

PAL was extracted from cherimoyas stored for 3 days at $20 \mathrm{C}$ in air (control), at $20 \mathrm{C}$ under $20 \% \mathrm{CO}_{2}\left(\mathrm{CO}_{2}\right)$ and at $6 \mathrm{C}$ in air (low temperature), and the kinetic properties were compared. The different enzyme extracts followed a hyperbolic Michaelis-Menten kinetic in a substrate (L-Phe) concentration ranging from $50 \mu \mathrm{m}$ to $10 \mathrm{mM}$, being saturated from $1 \mathrm{mM}$ (data not shown). However, the Lineweaver-Burk plot of initial rate data revealed the special kinetic characteristics of the enzymes extracted from cherimoyas stored under 
the different environmental conditions analyzed (Fig. 1). For PAL extracted from fruit stored for 3 days at $20 \mathrm{C}$ in air, the estimation of the kinetic parameters from experimental data yielded a $K_{\mathrm{m}}$ value of $40 \pm 2 \mu \mathrm{M}$ for L-Phe and a $V_{\max }$ of $44.6 \pm 0.7 \mathrm{nmol} / \mathrm{h} / \mathrm{mg}$ protein (Fig. 1A and Table 1). However, for PAL enzyme extracted from fruit treated with $\mathrm{CO}_{2}$ and fruit stored at low temperature, the Lineweaver-Burk plots bent downward, showing two distinct regions, which could be fitted with different straight lines depending on the range of L-Phe assayed (Fig. 1B,C). The kinetic enzyme constants were designated $K_{\mathrm{m}}{ }^{\mathrm{H}}$ and $K_{\mathrm{m}}{ }_{\mathrm{L}}, V_{\max }{ }^{\mathrm{H}}$ and $V_{\max }{ }^{\mathrm{L}}$ according to Tanaka and Uritani (1977).

The estimation of the kinetic constants for the enzyme extracted from cherimoya tissues stored at $20 \mathrm{C}$ under $20 \% \mathrm{CO}_{2}$ atmosphere was calculated by extrapolation as $K_{\mathrm{m}}{ }^{\mathrm{H}}=49 \pm 4 \mu \mathrm{M}$ and $K_{\mathrm{m}}{ }^{\mathrm{L}}=112 \pm 5 \mu \mathrm{M}$. $V_{\max }$ values were comparable: $49.3 \pm 0.9 \mathrm{nmol} / \mathrm{h} / \mathrm{mg}$ protein for low and $50.8 \pm 1.1 \mathrm{nmol} / \mathrm{h} / \mathrm{mg}$ protein for high substrate concentrations (Table 1). These $V_{\max }$ values were also similar to that found for PAL enzyme of fruit stored in air at 20C. However, PAL from fruit stored in air at $6 \mathrm{C}$ presented lower $V_{\max }$ values for both low and high substrate concentrations $\left(V_{\max }{ }^{\mathrm{L}}=23.2 \pm 0.5 \mathrm{nmol} / \mathrm{h} / \mathrm{mg}\right.$ protein and $V_{\max }{ }^{\mathrm{H}}=26.0 \pm 0.4 \mathrm{nmol} / \mathrm{h} / \mathrm{mg}$ protein). Also, $K_{\mathrm{m}}$ was lower at low substrate concentration $\left(K_{\mathrm{m}}{ }^{\mathrm{L}}=28 \pm 3 \mu \mathrm{M}\right)$ and higher at high L-Phe concentrations $\left(K_{\mathrm{m}}{ }^{\mathrm{H}}=164 \pm 4 \mu \mathrm{M}\right)$ (Table 1$)$.

Over the linear range of low substrate concentration $(0.050$ to $2.5 \mathrm{mM})$, PAL extracted from air and $\mathrm{CO}_{2}$-treated fruit stored at $20 \mathrm{C}$ displayed similar regulatory properties, whereas PAL extracted from fruit stored at low temperature showed a lower $V_{\max }$ and a higher substrate affinity. In spite of the differences in kinetic parameters, the specificity constant values (defined as the ratio $V_{\max } / K_{\mathrm{m}}$ ) were similar for all the treatments (Table 1), indicating that the efficiency of the reaction catalyzed by PAL was not affected by low temperature at low L-Phe concentration. However, over the linear range of high substrate concentration ( 1 to $10 \mathrm{mM}$ ), the regulatory properties of PAL enzyme extracted from cherimoyas stored under different environmental storage conditions revealed an additional enzyme regulation system. The affinity for L-Phe and the specificity constant values of PAL enzymes extracted from fruit treated with $\mathrm{CO}_{2}$ and fruit stored at low temperature (Table 1) decreased, mainly in fruit stored at low temperature storage where the PAL enzyme reached the lowest $V_{\max }$ and highest $K_{\mathrm{m}}$ values.

Kinetic characterization of cherimoya PAL showed that the $V_{\max }$ values of the enzymes were lower than those reported by other authors such as Shaw et al. (1990) for crude enzyme extract from potato tuber disks or Kim et al. (1996) for partially purified enzyme from Ustilago maydis. However, the affinities of the enzyme for L-Phe revealed a complex kinetics, similar to those previously reported by PAL proteins from other species, with $K_{\mathrm{m}}$ values ranging from 11 to $450 \mu \mathrm{M}$ for L-Phe (Hanson and Havir 1981; Jorrin and 

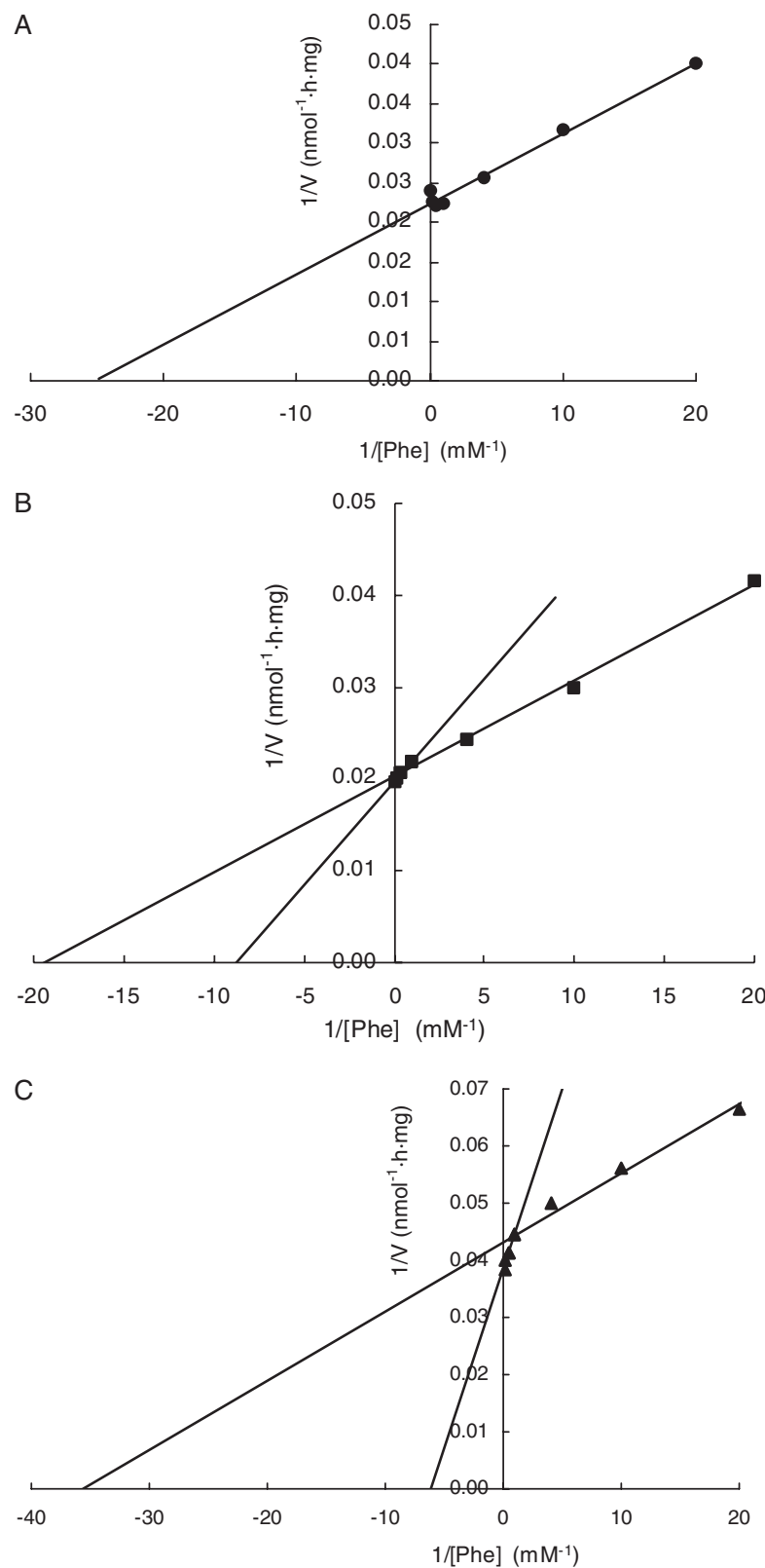

FIG. 1. LINEWEAVER-BURK DOUBLE RECIPROCAL PLOTS OF INITIAL RATE DATA FOR CHERIMOYA PHENYLALANINE AMMONIA-LYASE

Enzyme was extracted from fruit stored for 3 days in (A) air at $20 \mathrm{C}(-),(B) 20 \% \mathrm{CO}_{2}$ at $20 \mathrm{C}$ or $(C)$ air at $6 \mathrm{C}(\boldsymbol{\Delta})$. Initial rate is the value obtained as $\mathrm{A}_{290} / \mathrm{h}$ at varying concentrations of L-phenylalanine, against a blank without substrate. 
TABLE 1.

KINETIC PARAMETERS FOR PHENYLALANINE AMMONIA-LYASE EXTRACTED FROM CHERIMOYA FRUIT UNDER DIFFERENT STORAGE CONDITIONS

\begin{tabular}{llll}
\hline Treatment & Kinetic parameters & $V_{\max } / K_{\mathrm{m}}$ & Hill coefficient \\
\hline Control & $V_{\max }=44.6 \pm 0.7$ & 1.11 & 1.11 \\
$K_{\mathrm{m}}=40 \pm 2$ & & 0.71 \\
$\mathrm{CO}_{2}$ & $V_{\max }{ }^{\mathrm{L}}=49.3 \pm 0.9$ & 1.01 & \\
& $K_{\mathrm{m}}^{\mathrm{L}}=49 \pm 4$ & & \\
& $V_{\max }{ }^{\mathrm{H}}=50.8 \pm 1.1$ & 0.454 & 0.64 \\
& $K_{\mathrm{m}}{ }^{\mathrm{H}}=112 \pm 5$ & & \\
Low temperature & $V_{\max } \mathrm{L}=23.2 \pm 0.5$ & 0.833 & \\
& $K_{\mathrm{m}}{ }^{\mathrm{L}}=28 \pm 3$ & & \\
& $V_{\max } \mathrm{H}=26.0 \pm 0.4$ & 0.159 & \\
& $K_{\mathrm{m}}{ }^{\mathrm{H}}=164 \pm 4$ & & \\
\hline
\end{tabular}

Data are means of $V_{\max }\left(\mathrm{nmol} / \mathrm{h} \mathrm{mg}\right.$ protein) and $K_{\mathrm{m}}(\mu \mathrm{M})$ values $\pm \mathrm{SE}$.

Dixon 1990; Shaw et al. 1990). In contrast, PAL from sunflower exhibited a single high $K_{\mathrm{m}}$ value of $0.27 \mathrm{mM}$ (Jorrin et al. 1988).

This behavior could indicate that the extract contained multisite enzymes with substrate binding sites of different affinities or multiple forms of the same enzyme. Because the reciprocal plots obtained from experimental data (Fig. 1B,C) are indistinguishable from plots obtained for a mixture of enzymes with different substrate affinities, or for one enzyme with multiple sites of different affinities, we fit the experimental data to the Hill equation and calculate an apparent value for the Hill coefficient $\left(n_{\text {app }}\right)$. We observed that, for cherimoya PAL stored at $20 \mathrm{C}$ in air the Hill coefficient was close to 1, whereas the slope of the Hill plot for PAL extracted from treated fruit was lower than 1 (with $n_{\text {app }}$ values of 0.71 and 0.64 for fruit treated with $\mathrm{CO}_{2}$ and fruit stored at low temperature, respectively; Fig. 2 and Table 1). These coefficients were calculated according to Segel (1975) for negative cooperativity, which indicates that the slope between the points corresponding to $0.5 V_{\max }$ and $0.75 V_{\max }$ was lower than 1.0 but approached 1.0 at very high and low substrate concentrations. Because the saturation plot looks qualitatively like a Michaelis-Menten curve but the double-reciprocal plot is downwardly concave and the Hill coefficient is less than 1, our results indicate negative substrate cooperativity for high L-Phe levels in PAL enzymes extracted from $\mathrm{CO}_{2}$-treated or low-temperature-stored fruit (Fig. 2B,C and Table 1). In these cases, the PAL enzyme responded almost normally to substrate variations in low substrate ranges but exhibited pronounced substrate inhibition at high endogenous L-Phe concentrations. This behavior is not unusual, having been reported for several other systems and 

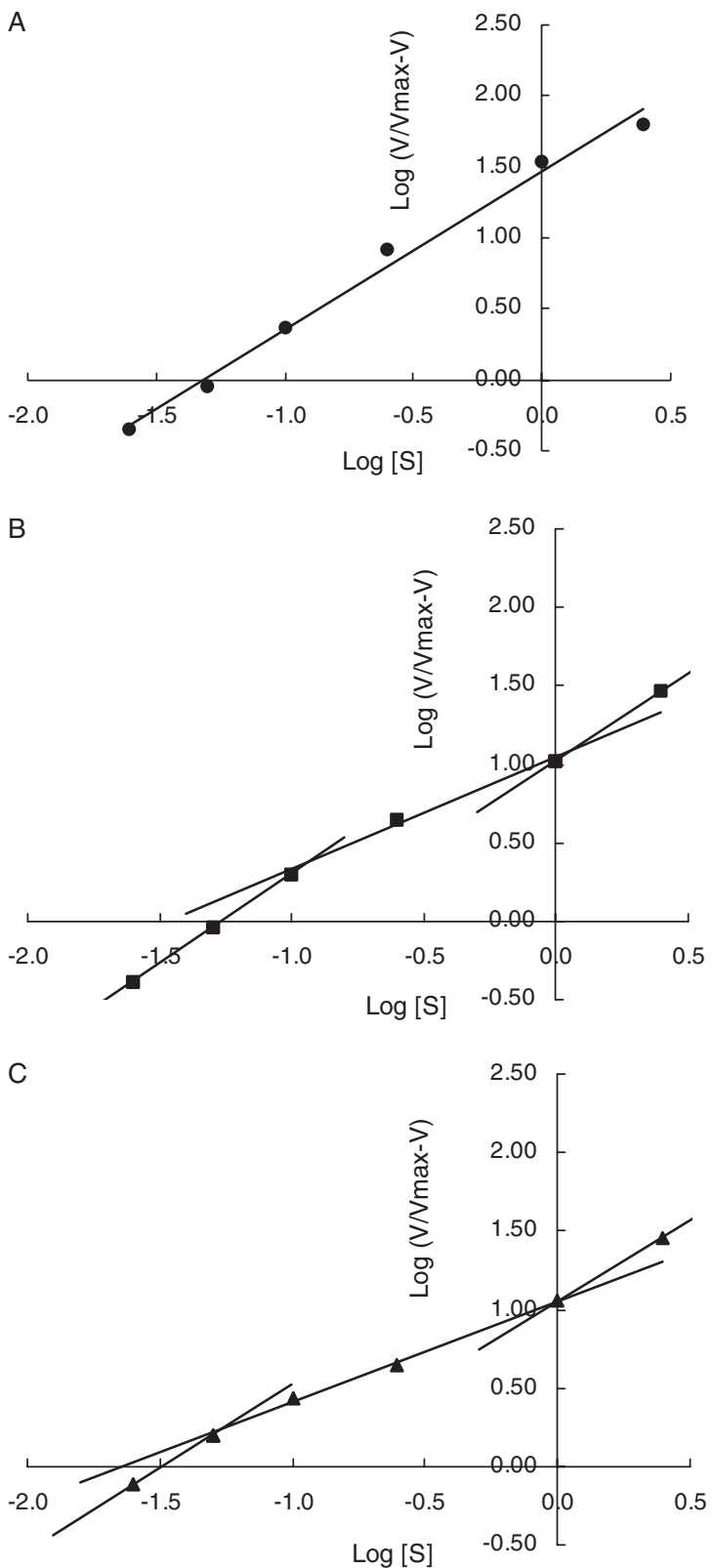

FIG. 2. HILL PLOT FOR CHERIMOYA PHENYLALANINE AMMONIA-LYASE

Enzyme was extracted from cherimoya fruit stored for 3 days in (A) air at $20 \mathrm{C}(\bullet)$, (B) $20 \% \mathrm{CO}_{2}$ at $20 \mathrm{C}(\boldsymbol{\square})$ or $(\mathrm{C})$ air at $6 \mathrm{C}(\boldsymbol{\Delta})$. 
TABLE 2 .

EFFECT OF DIFFERENT AMMONIUM-RELATED COMPOUNDS ON CHERIMOYA PHENYLALANINE AMMONIA-LYASE ACTIVITY

\begin{tabular}{lllr}
\hline $\begin{array}{l}\text { Compound } \\
(16 \mathrm{mM})\end{array}$ & \multicolumn{2}{l}{$\mathrm{NH}_{2}-\mathrm{R}$} & \\
\cline { 2 - 4 } & $\mathrm{R}$ & $\mathrm{pK}$ & Relative activity (\%) \\
\hline Ammonia & $-\mathrm{H}$ & 9.25 & $33.3 \pm 4$ \\
Glycine & $-\mathrm{CH}_{2}-\mathrm{COOH}$ & 9.60 & $103.7 \pm 5$ \\
L-Alanine & $-\mathrm{CH}-\mathrm{COOH}$ & 9.87 & \\
& $\mathrm{I}$ & & \\
& $\mathrm{CH}_{3}$ & & \\
L-Asparagine & $-\mathrm{CH}-\mathrm{COOH}$ & 8.80 & \\
& $\mathrm{I}$ & & \\
& $\mathrm{CH}$ & & \\
& $\mathrm{I}$ & & \\
& $\mathrm{CO}-\mathrm{NH}_{2}$ & & \\
\end{tabular}

The enzyme assay was conducted in the presence of 10-mM L-phenylalanine at $\mathrm{pH} 8.8$. Relative activity is expressed as a percentage of a control lacking any addition.

for most of the PAL enzyme from higher plants (Hanson and Havir 1981; Bolwell 1992; Dubery and Smit 1994).

The fact that PAL has generally been categorized as a tetrameric enzyme, added to the alosteric behavior described, suggests that cherimoya PAL enzyme could be oligomeric. Such negative cooperativity at high L-Phe levels of PAL extracted from low-temperature-stored cherimoya may explain in part the reported significant early decrease in PAL activity during postharvest cold storage (Maldonado et al. 2002b). In fruit at this stage, day 3 at $6 \mathrm{C}$, we also reported that ammonia reassimilation did not take place and that levels of endogenous ammonia increased up to almost $2 \mathrm{mM}$ (Maldonado et al. 2002a).

\section{Regulation of Cherimoya PAL Enzyme by Endogenous Effectors}

The effects of different compounds with a $-\mathrm{NH}_{2}$ group at $16-\mathrm{mM}$ concentration on cherimoya PAL activity were evaluated. The strength of inhibition for the molecules tested is reported in Table 2. The results indicate that ammonia specifically exerted an inhibitory effect on cherimoya PAL enzyme. It had previously been reported that L-alanine, DL-glutamic acid and ammonium ion produced no inhibition and that glycine was a weak inhibitor of the enzyme (Tanaka and Uritani 1977; Alunni et al. 2003). Our results would therefore indicate that the inhibiting effect of ammonia was not a general characteristic of compounds with one amino group. 


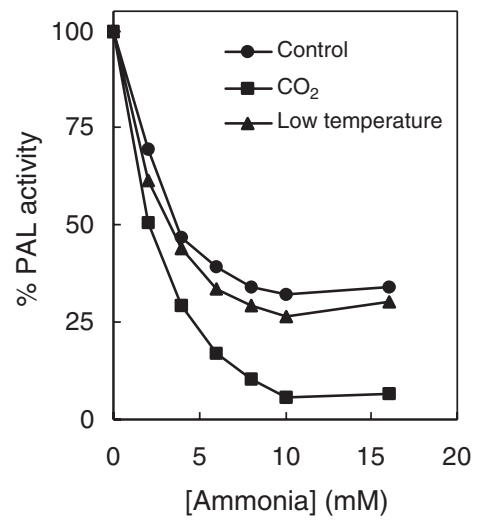

FIG. 3. CONCENTRATION-RELATED INHIBITORY EFFECT OF AMMONIA ON PHENYLALANINE AMMONIA-LYASE ACTIVITY

Enzyme was extracted from cherimoya fruit stored for 3 days in air at $20 \mathrm{C}(\bullet), 20 \% \mathrm{CO}_{2}$ at $20 \mathrm{C}$

(ם) or air at 6C $(\mathbf{\Delta})$.

We analyzed the effect of increasing ammonia levels on PAL activity extracted from fruit stored for 3 days at 20C in air (control), at 20C under 20\% $\mathrm{CO}_{2}\left(\mathrm{CO}_{2}\right)$ and at $6 \mathrm{C}$ in air (low temperature) (Fig. 3). In all cases, when an increasing amount of ammonia was added to the standard assay mixture, PAL activity decreased sharply. In the presence of $10 \mathrm{mM}$ of ammonia, the point of maximum PAL activity inhibition, about $75 \%$, was reached in control and low temperature cherimoyas. At this ammonia concentration, the inhibition of PAL activity was total in fruit stored under high levels of $\mathrm{CO}_{2}$.

Likewise, the ammonia concentration required to produce $50 \%$ inhibition ( $\left.\mathrm{I}_{50}\right)$ was determined by semilogarithmic plots of the dose-response curve of mesocarp PAL activity in the presence of ammonia. The ammonia $\mathrm{I}_{50}$ values for PAL of fruit stored in air at 20 and $6 \mathrm{C}$ were $4.0 \pm 0.2 \mathrm{mM}$ and $3.2 \pm 0.2 \mathrm{mM}$, respectively. The $\mathrm{I}_{50}$ value for the inhibition of PAL reached $2.0 \pm 0.1 \mathrm{mM}$ in the case of enzyme extracted from fruit stored with $20 \%$ $\mathrm{CO}_{2}$. These results confirm the inhibitory effect of ammonia on PAL activity. Also, the higher sensitivity of $\mathrm{CO}_{2}$-treated fruits to ammonia inhibition of tissues is consistent with the low concentrations of free ammonia quantified in these fruits, possibly the result of consumption due to massive accumulation of nitrogenous compounds (Merodio et al. 1998; Muñoz et al. 1999).

These results were produced in standard enzyme assay conditions $(\mathrm{pH}$ 8.8 ), where the ammonia/ammonium ion proportions were $26 \% \mathrm{NH}_{3}$ to $74 \%$ $\mathrm{NH}_{4}{ }^{+}$. Inhibition studies were also performed in control fruit at $\mathrm{pH} 9.25$ where the ammonia/ammonium ion proportion was $50 \% \mathrm{NH}_{3}$ to $50 \% \mathrm{NH}_{4}{ }^{+}$. Under these conditions, the semilogarithmic plot of the dose-response curves showed 
that the $\mathrm{I}_{50}$ value decreased to $0.40 \pm 0.03 \mathrm{mM}$. This result indicates that $\mathrm{NH}_{3}$ is a more powerful inhibitor than $\mathrm{NH}_{4}{ }^{+}$and suggests that the inhibitory mechanism could be related to the nucleophilic nature of this molecule. In this connection, affinity-label experiments have demonstrated that a nucleophile could react with the prosthetic electrophile at the active sites of two subunits of PAL from potato, maize and Rhodotorula glutinis (Havir and Hanson 1975). Recently, Poppe and Rétey (2005; and references therein) discovered that the active site of PAL is a superelectrophilic 5-methylene-3,5-diyroimidazol-4one prosthetic group.

The fact that ammonia inhibits the PAL enzyme is of particular importance, given that PAL is considered to be the branch point enzyme between primary (shikimate pathway) and secondary (phenylpropanoid) metabolism. It is also worth emphasizing that the carbon : nitrogen balance in fruit metabolic processes can be regulated to some extent by activation/deactivation of the phenylpropanoid pathway. The inhibition of the phenylpropanoid pathway by high ammonia levels may prove to be essential in adjusting PAL catalytic activity to the carbon skeleton demand required for ammonium assimilation.

\section{Kinetic Analysis of the Inhibition of PAL by Ammonia}

The inhibitory effect of ammonia on the reaction catalyzed by PAL was evaluated by kinetic analysis. These studies addressed the linear relationship exhibited over a range of substrate concentration from $50 \mu \mathrm{M}$ to $2.5 \mathrm{mM}$. In the presence of 1 and $3 \mathrm{mM}$ of ammonia, the Michaelis-Menten hyperbolic plots showed a progressive decrease in enzyme-substrate saturation (data not shown). The Lineweaver-Burk plots of initial velocities versus variable substrate concentrations clearly indicated mixed inhibition of PAL cherimoya enzyme by ammonia (Fig. 4). This behavior was further confirmed by determining the effect of ammonia on kinetic constants of the enzyme. These analyses revealed a decrease in the $V_{\max }$ and the affinity of PAL enzyme toward its substrate, L-Phe (Table 3). The values of $V_{\text {max }}^{\prime}$ and $K_{\mathrm{m}}^{\prime}$ in the presence of $1-\mathrm{mM}$ ammonia were $39.1 \pm 0.6 \mathrm{nmol} / \mathrm{h} / \mathrm{mg}$ protein and $66 \pm 2 \mu \mathrm{M}$, respectively. When an inhibitor concentration of $3 \mathrm{mM}$ was assayed, the apparent kinetic values were $22.6 \pm 0.4 \mathrm{nmol} / \mathrm{h} / \mathrm{mg}$ protein and $113 \pm 5 \mu \mathrm{M}$, respectively.

The inhibition constants $K_{\mathrm{i}}$ and $K_{\mathrm{i}}{ }^{\prime}$ for this mixed inhibitor were determined by replots of slope or reciprocal apparent maximal velocities $\left(1 / V_{\max }^{\prime}\right)$ obtained from primary Lineweaver-Burk plots versus the inhibitor concentration. In the secondary plots, the intercept on the inhibitor axis gives $-K_{\mathrm{i}}$ and $-K_{\mathrm{i}}^{\prime}$ (Segel 1975). This calculation rendered $K_{\mathrm{i}}$ and $K_{\mathrm{i}}^{\prime}$ values of $0.57 \pm 0.2 \mathrm{mM}$ and $2.54 \pm 0.2 \mathrm{mM}$, respectively. This result was comparable to the $K_{\mathrm{i}}$ value $(0.41 \mathrm{mM})$ reported for partially purified PAL of $U$. maydis by trans-cinnamic acid (Kim et al. 1996). $K_{\mathrm{i}}$ values of 57 and $130 \mu \mathrm{M}$ have been 


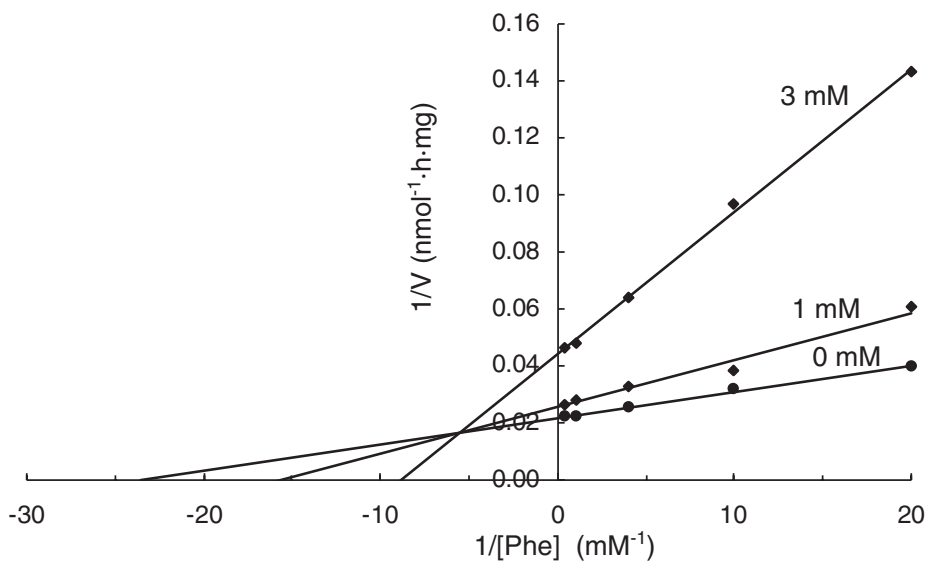

FIG. 4. KINETICS OF INHIBITORY EFFECT OF AMMONIA ON PHENYLALANINE AMMONIA-LYASE ACTIVITY

PAL activity kinetic in crude extracts of cherimoya fruit in the presence of different ammonia concentrations. Velocity measurements were made at various L-phenylalanine concentrations (mM).

The results are shown as a Lineweaver-Burk plot.

TABLE 3.

EFFECT OF AMMONIA ON KINETIC PARAMETERS FOR PHENYLALANINE AMMONIA-LYASE EXTRACTED FROM CONTROL CHERIMOYA TISSUES

\begin{tabular}{lll}
\hline Ammonium $(\mathrm{mM})$ & Kinetic parameters & $V_{\max } / K_{\mathrm{m}}$ \\
\hline 0 & $V_{\max }=45.9 \pm 0.7$ & 1.12 \\
& $K_{\mathrm{m}}=41 \pm 2$ & \\
1 & $V_{\max }^{\prime}=39.1 \pm 0.6$ & 0.59 \\
& $K_{\mathrm{m}}^{\prime}=66 \pm 2$ & \\
3 & $V_{\max }^{\prime}=22.6 \pm 0.4$ & 0.20 \\
& $K_{\mathrm{m}}^{\prime}=113 \pm 5$ & \\
\hline
\end{tabular}

Data are means of $V_{\max }\left(\mathrm{nmol} / \mathrm{h} / \mathrm{mg}\right.$ protein) and $K_{\mathrm{m}}(\mu \mathrm{M})$ values $\pm \mathrm{SE}$.

reported for the competitive inhibition of purified PAL from Ocimum basilicum leaves by trans-cinnamic acid and trans-methyl cinnamate, respectively (Hao et al. 1996). Studies of the mechanism of inhibition of PAL from $R$. glutinis by phenol inhibitors and phenol/glycine synergistic inhibitors showed that phenol, $o$-cresol, $m$-cresol and phenol/glycine and $o$-cresol/glycine pairs produced mixed inhibition in which $K_{\mathrm{i}}$ and $K_{\mathrm{i}}^{\prime}$ values for $o$-cresol were similar 
to those described for ammonia inhibition (Alunni et al. 2003). We are unaware of any prior reports regarding the effect of mixed-type inhibition of ammonia on PAL activity.

Given that cherimoya PAL enzyme is probably multimeric and the ammonia inhibitor is nucleophilic, we propose that the inhibitor binds at one of the active sites, modulating further substrate binding. This model is consistent with the one described by Alunni et al. (2003) for other PAL mixed inhibitors.

\section{CONCLUSIONS}

Our study of the kinetic properties of PAL shows that this enzyme is highly regulated in cherimoya fruit. Because large quantities of polyphenol compounds are deposited in Annona fruit cells, the energy cost in these fruits in terms of phenylalanine requirement is high. We observed that the enzyme displays negative substrate regulation when cellular L-Phe is accumulated at concentrations in excess of $1 \mathrm{mM}$. We also found that ammonia regulated the activity of this key enzyme, an additional regulatory mechanism that ensures that the phenylalanine requirements of other anabolic pathways are met, by subsequent reduction of its conversion into cinnamic acid. In the absence of de novo enzyme synthesis, the complex kinetic behavior of PAL probably plays an important role in regulating enzyme activity in vivo in Annona fruit, possibly in response to the cellular metabolic changes imposed by different postharvest storage conditions.

\section{ACKNOWLEDGMENTS}

This work was supported by research grants (Projects AGL2002-02308 and AGL2005-04502) from the Comisión Interministerial de Ciencia y Tecnología (CICYT), Spain. R.M. and O.G. were supported by a predoctoral fellowship from MEC, Spain.

\section{REFERENCES}

ALIBERT, G., RANJEVA, R. and BOUDET, A. 1972. Studies on enzymes catalyzing phenolic acids formation in Quercus penduculata (Ehrh.). II. Intracellular location of phenylalanine ammonia-lyase, cinnamate 4-hydroxylase and "benzoate synthase." Biochim. Biophys. Acta 279, 282-289. 
ALLWOOD, E.G., DAVIES, D.R., GERRISH, C., ELLIS, B.E. and BOLWELL, G.P. 1999. Phosphorylation of phenylalanine ammonialyase: Evidence for a novel protein kinase and identification of the phosphorylated residue. FEBS Lett. 457, 47-52.

ALUNNI, S., CIPICIANI, A., FORONI, G. and OTTAVI, L. 2003. Mechanisms of inhibition of phenylalanine ammonia-lyase by phenol inhibitors and phenol/glycine synergistic inhibitors. Arch. Biochem. Biophys. 412, $170-175$.

APPERT, C., LOGERMANN, E., HAHLBROCK, K., SCHMID, J. and AMRHEIN, N. 1994. Structural and catalytic properties of the four phenylalanine-lyase isoenzymes from parsley (Petroselinum crispum Nym.). Eur. J. Biochem. 225, 491-499.

ASSIS, J.S., MALDONADO, R., MUÑOZ, T., ESCRIBANO, M.I. and MERODIO, C. 2001. Effect of high carbon dioxide concentration on PAL activity and phenolic contents in ripening cherimoya fruit. Postharvest Biol. Technol. 23, 33-39.

BERNARDS, M.A. and ELLIS, B.E. 1991. Phenylalanine ammonia-lyase from tomato cell cultures inoculated with Verticillum albo-atrum. Plant Physiol. 97, 1494-1500.

BOLWELL, G.P. 1992. A role for phosphorylation in the down-regulation of phenylalanine ammonia-lyase in suspension-culture cells of French bean. Phytochemistry 31, 4081-4086.

BRADFORD, M. 1976. A rapid and sensitive method for the quantification of microgram quantities of protein utilizing the principle of protein-dye binding. Anal. Biochem. 72, 248-254.

CAMPOS, R., NONOGAKI, H., SUSLOW, T. and SALTVEIT, M.E. 2004. Isolation and characterization of a wound inducible phenylalanine ammonia-lyase gene ( $L S P A L 1)$ from Romaine lettuce leaves. Physiol. Plant. 121, 429-438.

CRAMER, C.I., EDWARDS, K., DRON, M., LIANG, X., DILDINE, S.L., BOLWELL, G.P., DIXON, R.A., LAMB, C.J. and SCHUCH, W. 1989. Phenylalanine ammonia-lyase gene organization and structure. Plant Mol. Biol. 12, 367-383.

DIXON, R.A. and LAMB, C.J. 1979. Stimulation of de novo synthesis of L-phenylalanine ammonia-lyase in relation to phytoalexin accumulation in Colletotrichum lindemuthianum elicitor-treated cell suspension cultures of French bean (Phaseolus vulgaris). Biochim. Biophys. Acta 586, 453-463.

DUBERY, I. and SMIT, F. 1994. Phenylalanine ammonia-lyase from cotton (Gossypium hirsutum) hypocotyls properties of the enzyme induced by a Verticillium dahliae phytotoxin. Biochim. Biophys. Acta 1207, 24-30. 
ENGELSMA, G. 1970. Photoinduction of phenylalanine deaminase in gherkin seedlings. IV. The role of the temperature. Planta 90, 133-141.

ESCRIBANO, M.I. and MERODIO, C. 1994. The relevance of polyamine levels in cherimoya (Annona cherimola Mill.) fruit ripening. J. Plant Physiol. 143, 207-212.

HANSON, K.R. and HAVIR, E.A. 1981. Phenylalanine ammonia-lyase. In The Biochemistry of Plants: A Comprehensive Treatise, Vol. 7, Secondary Plant Products (E.E. Conn, ed.) pp. 577-625, Academic Press, London and New York.

HAO, Z., CHARLES, D.J., YU, L. and SIMON, J.E. 1996. Purification and characterization of phenylalanine ammonia-lyase from Ocimum basilicum. Phytochemistry 43, 735-739.

HAVIR, E.A. and HANSON, K.R. 1975. L-Phenylalanine ammonia-lyase (maize, potato, and Rhodotorula glutinis). Studies of the prosthetic group with nitromethane. Biochemistry 14, 1620-1626.

HISAMINATO, H., MURATA, M. and HOMMA, S. 2001. Relationship between the enzymatic browning and phenylalanine ammonialyase activity of cut lettuce and prevention of browning by inhibitors of polyphenol biosynthesis. Biosci. Biotechnol. Biochem. 65, 10161021.

JORRIN, J. and DIXON, R.A. 1990. Stress responses in alfalfa (Medicago sativa L.). II. Purification, characterization, and induction of phenylalanine ammonia-lyase isoforms from elicitor-treated cell suspension cultures. Plant Physiol. 92, 447-455.

JORRIN, J., LOPEZ-VALBUENA, R. and TENA, M. 1988. Purification and properties of phenylalanine ammonia-lyase from sunflower (Helianthus annuus L.) hypocotyls. Biochim. Biophys. Acta 964, 73-82.

KE, D. and SALTVEIT, M.E. 1989. Wound-induced ethylene production, phenolic metabolism and susceptibility to russet spotting in iceberg lettuce. Physiol. Plant. 76, 412-418.

KIM, S.H., KRONSTAD, J.W. and ELLIS, B.E. 1996. Purification and characterization of phenylalanine ammonia-lyase from Ustilago maydis. Phytochemistry 43, 351-357.

LAFUENTE, M.T., ZACARIAS, L., MARTÍNEZ-TELLEZ, M.A., SANCHEZ-BALLESTA, M.T. and DUPILLE, E. 2001. Phenylalanine ammonia-lyase as related to ethylene in the development of chilling symptoms during cold storage of citrus fruits. J. Agric. Food Chem. 49, 6020-6025.

LIM, H.W., SA, J.H., KIM, T.S., PARK, S.S. and LIM, C.J. 1998. Purification and properties of phenylalanine ammonia-lyase from Chinese cabbage. J. Biochem. Mol. Biol. 31, 31-36. 
LOGEMANN, E., PARNISKE, M. and HAHLBROCK, K. 1999. Modes of expression and common structural features of the complete phenylalanine ammonia-lyase gene family in parsley. Proc. Natl. Acad. Sci. USA 92, 5905-5909.

LÓPEZ-GÁlVEZ, G., SALTVEIT, M.E. and CANTWELL, M. 1996. Wound-induced phenylalanine ammonia lyase activity, factors affecting its induction and correlation with the quality of minimally processed lettuce. Postharvest Biol. Technol. 9, 223-233.

MALDONADO, R., ESCRIBANO, M.I. and MERODIO, C. 2002a. Relationship between the levels of ammonia and co-ordination of phenylalanine ammonia-lyase and phosphoenolpyruvate carboxylase in Annona cherimola stored under different conditions. Postharvest Biol. Technol. 25, 301-309.

MALDONADO, R., MOLINA-GARCÍA, A.D., SANCHEZ-BALLESTA, M.T., ESCRIBANO, M.I. and MERODIO, C. 2002b. High $\mathrm{CO}_{2}$ atmosphere modulating the phenolic response associated with cell adhesion and hardening of Annona cherimola fruit stored at chilling temperature. J. Agric. Food Chem. 50, 7564-7569.

MERODIO, C., MUÑOZ, M.T., DEL CURA, B., BUITRAGO, M.D. and ESCRIBANO, M.I. 1998. Effect of high $\mathrm{CO}_{2}$ levels on the titers of $\alpha$-aminobutyric acid, total polyamines and some pathogenesis-related proteins in cherimoya fruit stores at low temperature. J. Exp. Bot. 49, 1339-1347.

MUÑOZ, T., AGUADO, P., ORTEGA, N., ESCRIBANO, M.I. and MERODIO, C. 1999. Regulation of ethylene and polyamine synthesis by elevated carbon dioxide in cherimoya fruit stored at ripening and chilling temperatures. Aust. J. Plant Physiol. 26, 201-209.

POPPE, L. and RÉTEY, J. 2005. Friedel-crafts-type mechanism for the enzymatic elimination of ammonia from histidine and phenylalanine. Angew. Chem. Int. Ed. 44, 3668-3688.

SALTVEIT, M.E., CHOI, Y. and TOMÁS-BARBERÁN, A. 2005. Mono-carboxylic acids and their salts inhibit wound-induced phenolic accumulation in excised lettuce (Lactuca sativa). Physiol. Plant. 125, 454-463.

SANCHEZ-BALLESTA, M.T., LAFUENTE, M.T., ZACARIAS, L. and GRANELL, A. 2000. Involvement of phenylalanine ammonia-lyase in the response of Fortune mandarin fruits to cold storage. Physiol. Plant 108, 382-389.

SARMA, A.D., SREELAKSHMI, Y. and SHARMA, R. 1998. Differential expression and properties of phenylalanine ammonia-lyase isoforms in tomato leaves. Phytochemistry 49, 2233-2243. 
SCHROEDER, C.A. 1951. Fruit morphology and anatomy of the cherimoya. Bot. Gaz. Chicago 6, 436-446.

SEGEL, H.I. 1975. Enzyme Kinetics, Wiley, New York, NY.

SHAW, N.M., BOLWELL, G.P. and SMITH, C. 1990. Wound-induced phenylalanine ammonia-lyase in potato (Solanum tuberosum) tuber discs. Significance of glycosylation and immunolocalization of enzyme subunits. Biochem. J. 267, 163-170.

SHUFFLEBOTTOM, D., EDWARDS, K., SCHUCH, W. and BEVAN, M. 1993. Transcription of two members of a gene family encoding phenylalanine ammonia-lyase leads to remarkably different cell specificities and induction patterns. Plant J. 3, 835-845.

TANAKA, Y. and URITANI, I. 1977. Purification and properties of phenylalanine ammonia-lyase in cut-injured sweet potato. J. Biochem. 81, 963970.

WEN, P.F., CHEN, J.Y., KONG, W.F., PAN, Q.H., WAN, S.B. and HUANG, W.D. 2005. Salicylic acid induced the expression of phenylalanine ammonia-lyase gene in grape berry. Plant Sci. 169, 928-934.

ZON, J. and AMRHEIN, N. 1992. Inhibitors of phenylalanine ammonia-lyase: 2-aminoindan-2-phosphonic acid and related compounds. Liebigs Ann. Chem. 6, 625-628. 